\title{
Pengaruh Suplementasi Karbohidrat Mudah Larut yang Berbeda dalam Pakan Berbasis Jerami Padi Amoniasi terhadap Degradabilitas Ruminal In Vitro
}

\author{
Effect of Different Soluble Carbohydrate Supplementation in the Ammoniated Rice Straw \\ Based Diet on its In Vitro Ruminal Degradability
}

\author{
I. P. Sari, L. K. Nuswantara dan J. Achmadi \\ Fakultas Peternakan dan Pertanian, Universitas Diponegoro \\ Corresponding e-mail: : purnamaita913@gmail.com
}

\begin{abstract}
This study clarified the in vitro ruminal degradability of ammoniated rice straw based diet (ARSB) with different supplementation of soluble carbohydrate. Two ammoniated rice straw based diets were supplemented with banana tree root ball (BTRB) or sugarcane molasses (SGM) as the source of readily available carbohydrate (RAC). The diets were designed to be isonitrogenous (12\% CP) and isoenergy $(60 \% \mathrm{TDN})$. The in vitro ruminal degradability was accomplished by a method of bath culture using rumen fluid of goat. Microbial protein production, dry and organic matter degradabilities, and ruminal $\mathrm{pH}$ were observed in the in vitro study. The ARSB had similar microbial protein production when supplemented with BRTB or SGM. The in vitro dry and organic matter degradabilities of ARSB were unaffected by different supplementation of the RAC. The different supplementation of RAC did not change the ruminal pH. It could be concluded that both BRTB and SGM may have similar role as source of RAC and binding agent for a complete feed, SGM could be substituted banana tree root ball in ARBS.
\end{abstract}

Key words: rice straw, sugarcane molasses, banana tree root ball, feed, in vitro

\begin{abstract}
ABSTRAK
Penelitian ini bertujuan untuk mengkaji degradabilitas ruminal secara in vitro pada pakan komplit berbasis jerami padi amoniasi (ARBS) dengan suplementasi kabrohidrat mudah larut yang berbeda. Dua pakan komplit berbasis jerami padi amoniasi yang ditambahkan dengan tepung bonggol pisang (BTRB) atau molases (SGM) sebagai sumber readily available carbohydrate (RAC). Pakan disusun dengan isoprotein (12\% PK) dan isoenergi $(60 \% \mathrm{TDN})$. Degradabilitas ruminal secara in vitro dilakukan dengan menggunakan cairan rumen kambing. Parameter yang diamati dalam penelitian yaitu produksi protein mikrobia, degradabilitas bahan kering dan bahan organik, dan $\mathrm{pH}$ rumen. Pakan berbasis jerami padi amoniasi (ARBS) memiliki produksi protein mikrobia yang sama ketika ditambahkan dengan tepung bonggol pisang (BTRB) atau molases (SGM). Degradabilitas Bahan kering dan bahan organik secara in vitro pada pakan komplit berbasis jerami padi amoniasi tidak terpengaruh oleh suplementasi RAC yang berbeda. Suplementasi RAC yang berbeda tidak mengubah $\mathrm{pH}$ rumen. Dapat disimpulkan bahwa tepung bonggol pisang dan molases memiliki kesamaan sebagai sumber RAC pada pakan komplit, sehingga tepung bonggol pisang dapat menggantikan molasses pada pakan komplit.
\end{abstract}

Kata kunci: Jerami padi, molases, tepung bonggol pisang, pakan, in vitro.

\section{PENDAHULUAN}

Indonesia adalah negara agraris dimana sebagian besar masyarakatnya bermata pencaharian sebagai petani. Padi merupakan tanaman pokok bagi masyarakat Indonesia sehingga setiap tahun produksi padi di Indonesia sangat melimpah. Limbah dari hasil pertanian padi ini salah satunya adalah jerami padi, yaitu hasil limbah dari tanaman padi yang telah diambil bulirnya.
Pemanfaatan jerami padi di Indonesia kurang optimal karena sebagian besar limbah tersebut belum termanfaatkan dengan baik.

Perbandingan antara produksi padi dan jerami yaitu diperkirakan sebesar $1: 1$. Pemanfaatan jerami padi untuk pakan ternak di Indonesia berkisar antara 31 - 39\% dan sebagian besar dibakar dan dikembalikan ketanah sebagai penutup tanah sekitar 36 $62 \%$ dan sisanya antara $7-16 \%$ digunakan untuk keperluan industri (Yuliana, 2008). 
Jerami padi dapat dimanfaatkan sebagai pakan alternatif pengganti hijauan ternak untuk jangka panjang. Sebagian kecil para peternak di pedesaan telah menggunakan jerami padi sebagai pengganti hijauan pada saat musim kemarau. Kelemahan yang dimiliki oleh jerami padi yaitu serat kasar yang tinggi sehingga daya cerna rendah, kandungan protein kasar rendah, kurang disukai ternak sehingga pemanfaatan jerami padi menjadi kurang optimal.

Oleh karena itu diperlukan suatu pengolahan untuk meningkatkan kandungan nutrien dan nilai guna jerami padi agar bisa menjadi pakan ternak yang berkualitas. Jerami padi bisa dilakukan pengolahan dengan cara amoniasi. Amoniasi yaitu suatu teknik pengolahan pakan dengan penambahan urea. Urea berfungsi sebagai pemecah ikatan lignin, selulosa dan silika sehingga bahan pakan dapat lebih lunak dan lebih mudah dicerna (Assakur, 2013). Kelemahan lain dari jerami padi yaitu tidak dapat dijadikan sebagai pakan tunggal karena daya cerna jerami padi dan kandungan nutrisinya yang rendah sehingga kurang memenuhi kebutuhan ternak, oleh karena itu perlu ditambahkan bahan pakan lain agar kebutuhan ternak dapat terpenuhi.

Pakan komplit merupakan komposisi dari baik hijauan (pakan kasar) maupun konsentrat dicampur menjadi satu (Indayani, 2014). Penambahan jerami padi amoniasi dalam pakan komplit tentunya harus diimbangi dengan sumber karbohidrat yang mudah terserap karena kandungan $\mathrm{N}$ dalam jerami padi amoniasi cukup tinggi. Penyusunan pakan komplit biasanya menggunakan molases sebagai sumber karbohidrat yang mudah terserap. Molases dikenal dengan pakan sumber karbohidrat mudah tersedia yang baik karena cepat terlarut dalam rumen (Suhada et al., 2016). Penggunaan molases dalam pakan memerlukan biaya yang lebih besar karena harganya yang mahal, selain itu molases juga bersaing penggunaannya dalam industri pangan. Tepung bonggol pisang memiliki kandungan nutrien yang terdiri dari bahan kering $17,46 \%$, abu $16,00 \%$, serat kasar
$14,50 \%$, lemak kasar 0,75\%, BETN 67,79\%, pati (karbohidrat) sebesar 66,2\%, serat kasar $10,23 \%$, protein $5,88 \%$ dan NFC $62,27 \%$ (Indah, 2016; Sutowo et al., 2016). Tepung bonggol pisang merupakan salah satu bahan pakan alternatif sumber karbohidrat yang mudah terserap dan dapat menggantikan molases dalam penyusunan pakan komplit.

Penelitian ini mengkaji degradabilitas ruminal secara in vitro pada pakan komplit berbasis jerami padi amoniasi dengan suplementasi kabrohidrat mudah larut yang berbeda. Manfaat yang diperoleh dari penelitian ini yaitu dapat memberikan informasi tentang penggunaan tepung bonggol pisang dalam penyusunan pakan komplit.

\section{MATERI DAN METODE}

Penelitian ini dilaksanakan pada bulan September 2017 - Januari 2018 di Laboratorium Ilmu Nutrisi dan Pakan, Departemen Peternakan, Fakultas Peternakan dan Pertanian Universitas Diponegoro Semarang.

Materi yang digunakan dalam penelitian ini yaitu alat yang terdiri dari gunting, trash bag, timbangan analitik, plastik, gelas ukur, grinder, blender, oven, tanur, crucible porselin, pipet tetes, kertas saring, pompa vacum, lemari asam, eksikator, tabung reaksi, erlenmeyer, saringan, termometer, termos, kain penyaring, $\mathrm{pH}$ meter, $\mathrm{pH}$ kertas, tabung fermentor, water bath, centrifuge, beaker glass, pipet ukur 1 $\mathrm{ml}$ dan $5 \mathrm{ml}$, kertas minyak, kertas saring Whatman 41 dan labu destilasi.

Bahan terdiri sampel jerami padi, alkohol $70 \%, \mathrm{H}_{2} \mathrm{SO}_{4}$, air panas, folin, auades, $\mathrm{NaOH} 0,1 \mathrm{~N}$, larutan aseton, natrium sulfat, pakan komplit dengan komposisi TDN 60\% dan PK $12 \%$ yang terdiri dari jerami padi, jagung giling, bekatul, onggok, tepung bonggol pisang, molases, urea, air bersih, cairan rumen dari kambing fistula jawarandu, gas $\mathrm{CO}_{2}$ dan cairan Mc Dougall. Metode yang digunakan dalam penelitian ini meliputi rancangan penelitian, prosedur penelitian dan analisis data. 
Rancangan Penelitian

Penelitian ini dirancang untuk membandingkan dua perlakuan, menggunakan pakan yang di susun dengan komposisi TDN $60 \%$ dan PK 12\% yang masing-masing mengandung sumber karbohidrat yang berbeda, perlakuan yang digunakan adalah :

$\mathrm{T} 1$ : (pakan + tepung bonggol pisang)

$\mathrm{T} 2:($ pakan + molases $)$

\section{Pembuatan Tepung Bonggol Pisang}

Bonggol pisang yang diperoleh dari bagian bawah akar pohon pisang disiapkan, kemudian kulit dan akar yang masih menempel pada bagian bonggol pisang di bersihkan dengan menggunakan sabit, lalu bonggol pisang yang sudah bersih dicacah hingga ukuran $\pm 10 \mathrm{~cm}$ untuk memudahkan proses penggilingan, kemudian bonggol pisang digiling, selanjutnya dilakukan proses pengeringan dibawah sinar matahari, kemudian dihaluskan dengan menggunakan grinder sampai berbentuk tepung.

\section{Amoniasi Jerami Padi}

Metode amoniasi jerami padi menggunakan metode Komar (1984) yaitu dengan cara jerami padi yang sudah kering dipotong-potong menjadi ukuran $5-10 \mathrm{~cm}$. Urea ditimbang sebanyak 4\% amonia dalam BK jerami padi. Air disiapkan sesuai dengan kadar air akhir yaitu 40\%, urea dilarutkan ke dalam air tersebut hingga homogen, larutan urea ditambahkan dalam jerami padi dan dicampur hingga merata seluruhnya. Selanjutnya jerami padi yang telah dicampur larutan urea dimasukkan ke dalam trashbag dan dipadatkan, kemudian ditutup dengan solatip agar tidak ada lubang atau sobekan lalu disimpan selama 3 minggu. Setelah 3 minggu kemudian jerami padi amoniasi diangin-anginkan dan dihaluskan menggunakan grinder dan blender sampai berbentuk tepung.

\section{Analisis Proksimat}

Analisis proksimat dilakukan untuk mengetahui kandungan nutrisi yang terdapat dalam bahan pakan Jerami Padi Amoniasi yang meliputi kadar air, kadar abu, lemak kasar, serat kasar dan protein kasar. Analisis serat kasar meliputi NDF dan ADF.

\section{Penyusunan Pakan}

Bahan pakan tersusun dari jerami padi amoniasi, bekatul, onggok, tepung bonggol pisang, molases, bungkil kedelai dan jagung. Pakan terdiri atas dua formulasi, yaitu pakan dengan molases dan pakan dengan tepung bonggol pisang. Pakan diformulasi dengan kandungan TDN $60 \%$ dan PK $12 \%$. Formulasi ransum selengkapnya dapat dilihat pada Tabel 1 dan 2 .

Parameter yang diambil meliputi pengukuran $\mathrm{pH}$, produksi protein mikrobia dan degradasi bahan kering dan bahan organik yaitu sebagai berikut.

\section{Pengukuran pH}

Metode yang digunakan dalam pengukuran $\mathrm{pH}$ yaitu dengan cara sampel yang telah diinkubasi selama 48 jam dalam tabung fermentor dimasukan kedalam beaker glass, kemudian mengukur $\mathrm{pH}$ dengan menggunakan kertas $\mathrm{pH}$ dan $\mathrm{pH}$ meter lalu hasil dicatat dalam buku catatan.

Tabel 1. Formulasi ransum dengan tepung bonggol pisang

\begin{tabular}{lcccc}
\hline \multicolumn{1}{r}{ Bahan Pakan } & Komposisi $(\%)$ & PK $(\%)$ & TDN $(\%)$ & NFC $(\%)$ \\
\hline Jerami padi amoniasi & 55,00 & 5,60 & 23,85 & 0,00 \\
Bekatul & 17,50 & 0,27 & 1,13 & 0,45 \\
Onggok & 7,35 & 0,04 & 4,00 & 3,09 \\
T. Bonggol pisang & 2,65 & 0,09 & 1,90 & 1,79 \\
Bungkil kedelai & 7,50 & 3,92 & 6,52 & 3,38 \\
Jagung & 10,00 & 2,15 & 22,59 & 9,36 \\
\hline & 100 & 12,08 & 60,00 & 18,07 \\
\hline
\end{tabular}


Tabel 2. Formulasi ransum dengan molases

\begin{tabular}{lcccc}
\hline Bahan Pakan & Komposisi $(\%)$ & PK $(\%)$ & TDN $(\%)$ & NFC $(\%)$ \\
\hline Jerami padi amoniasi & 55,00 & 5,60 & 23,85 & 0,00 \\
Bekatul & 17,75 & 0,40 & 1,70 & 0,68 \\
Onggok & 7,75 & 0,04 & 4,24 & 3,26 \\
Molases & 2,00 & 0,02 & 1,68 & 1,82 \\
Bungkil kedelai & 7,50 & 3,94 & 6,55 & 3,40 \\
Jagung & 10,00 & 2,10 & 21,98 & 9,10 \\
\hline & 100,00 & 12,10 & 60,00 & 18,27 \\
\hline
\end{tabular}

\section{Fermentasi Pakan}

Alat dan bahan yang digunakan seperti tabung fermentor, beaker glass, gelas ukur $10 \mathrm{ml}$ dan $50 \mathrm{ml}$ yang telah di sterilisasi, karet penutup, pipet tetes disiapkan dan bahan yang meliputi sampel pakan, cairan rumen, larutan Mc Dougall. Kemudian tabung fermentor diisi dengan 0,5 gram sampel ditambah $40 \mathrm{ml}$ larutan Mc Dougall. Tabung dimasukkan kedalam water bath dengan suhu $39^{\circ} \mathrm{C}$ selama 15 menit. Setelah itu tabung ditambah $10 \mathrm{ml}$ cairan rumen dengan dialiri $\mathrm{CO}_{2}$, kemudian tabung ditutup dengan karet berventilasi, lalu dilakukan fermentasi selama 48 jam, setiap 6 jam dilakukan penggojokan. Setelah 48 jam, tutup fermentor dibuka, kemudian sampel dimasukkan kedalam tabung reaksi dan dilakukan centrifuge selama 15 menit dengan kecepatan $3000 \mathrm{rpm}$. Setelah 15 menit centrifuge dimatikan dan substrat akan terpisah menjadi endapan dibagian bawah dan supernatan yang bening berada dibagian atas.

\section{Pengukuran Produksi Protein Mikrobia}

Residu dari hasil inkubasi fermentasi mikrobia rumen di centrifuge dengan dengan kecepatan $3.000 \mathrm{rpm}$ selama 15 menit. Supernatan yang diperoleh digunakan untuk analisis protein mikrobia rumen. Konsentrasi protein mikrobia diukur menggunakan metode Lowry (Plummer, 1971). Supernatan hasil sentrifuse $3.000 \mathrm{rpm}$ kemudian disentrifuse kembali pada kecepatan 8.000 rpm. Endapan hasil sentrifuse $8.000 \mathrm{rpm}$ diambil dan ditambahkan $1 \mathrm{ml} \mathrm{NaOH} 0,1 \mathrm{~N}$, dihomogenkan menggunakan vortex kemudian dipanaskan pada suhu $90^{\circ} \mathrm{C}$ selama 10 menit. Filtrat sampel sebanyak 1 ml dimasukkan dalam tabung reaksi, kemudian ditambahkan $5 \mathrm{ml}$ larutan Lowry dan dihomogenkan, didiamkan selama 10 menit. Setelah itu ditambahkan $0,5 \mathrm{ml}$ larutan folin dan didiamkan selama 30 menit pada suhu kamar, kemudian dibaca pada spektrofotometer dengan panjang gelombang $750 \mathrm{~nm}$. Satuan sintesis protein mikrobia dengan metode Lowry adalah $\mathrm{mg} / \mathrm{g}$ dan dapat dihitung dengan menggunakan rumus sebagai berikut :

Sintesis Protein Mikrobia (mg/g) :

konsentrasi larutan x Pengencer x Indukan Bobot Sampel

\section{Pengukuran Degradasi Bahan Kering dan Bahan Organik}

Degradasi bahan kering dan bahan organik menggunakan metode Tilley and Terry (1963) yaitu Setelah proses fermentasi yang telah dilaksanakan selama 48 jam kemudian sampel disaring dengan menggunakan kertas saring Whatman 41 dengan bantuan pompa vakum. Kemudian sampel dalam kertas saring dimasukkan ke dalam crucible porselin dan dikeringkan dengan menggunakan oven selama 24 jam. Selanjutnya bahan dalam cawan dipijarkan atau diabukan dalam tanur listrik selama 6 jam pada suhu $450-600{ }^{\circ} \mathrm{C}$.

Degradasi Bahan Kering dan Bahan Organik dapat dihitung dengan menggunakan rumus sebagai berikut :

Degradasi BK $(\%)=$

$\frac{\text { BK Sampel (g) - (BK Residu (g) - BK Blanko (g)) }}{\text { BK Sampel (g) }} \times 100 \%$ 
Degradasi BO $(\%)=$

$\frac{\text { BO Sampel (g) - (BO Residu (g) - BO Blanko (g)) }}{\text { B0 Sampel (g) }} \times 100 \%$

\section{HASIL DAN PEMBAHASAN}

Tabel 3. Karakteristik in vitro

\begin{tabular}{lcc}
\hline \multirow{2}{*}{\multicolumn{1}{c}{ Parameter }} & \multicolumn{2}{c}{ Perlakuan } \\
\cline { 2 - 3 } & $\mathrm{T} 1$ & $\mathrm{~T} 2$ \\
\hline pH Rumen & 6,63 & 6,55 \\
Protein Mikrobia (mg/g) & 413,89 & 432,77 \\
Degradasi Bahan Kering (\%) & 68,99 & 67,01 \\
Degradasi Bahan Organik $(\%)$ & 69,69 & 65,74 \\
\hline
\end{tabular}

\section{pH Rumen}

Hasil pengukuran $\mathrm{pH}$ rumen pada $\mathrm{T} 1$ dan T2 menunjukan angka yang normal yaitu 6,63 dan 6,55 sebagaimana hasil yang dilaporkan oleh Amri dan Yurleni (2014) yang menyatakan bahwa $\mathrm{pH}$ rumen dalam kondisi normal untuk pertumbuhan mikrobia dalam rumen yaitu berada pada kisaran 6,0 6,9 pada temperatur $39^{\circ} \mathrm{C}$. Usman (2013) menyatakan bahwa $\mathrm{pH}$ cairan rumen yang normal adalah 6,0 - 7,0 dengan temperatur $38-41^{\circ} \mathrm{C}$ pada lingkungan anaerob.

Hasil diatas menunjukan bahwa nilai $\mathrm{pH}$ pada pakan yang ditambah dengan tepung bonggol pisang tidak berbeda nyata $(p>0,05)$ terhadap derajat keasaman dalam rumen yang berarti pakan yang ditambahkan tepung bonggol pisang dan molases memiliki kesamaan, sehingga nilai $\mathrm{pH}$ keduanya tidak berbeda dan masih berada dalam kisaran normal. Kesamaan pada kedua perlakuan tersebut disebabkan karena nilai energi yang disusun dalam pakan sama sehingga menghasilkan nilai VFA yang sama pula, karena nilai VFA yang diperoleh berpengaruh terhadap nilai derajat keasaman $(\mathrm{pH})$ yang dihasilkan. Apabila nilai VFA yang diperoleh tinggi, maka nilai $\mathrm{pH}$ akan rendah yang berarti asam, dan apabila nilai VFA yang diperoleh rendah maka kondisi pH akan mendekati netral. Nilai VFA yang dihasilkan pada perlakuan 1 (pakan yang ditambahkan tepung bonggol pisang) yaitu $63,33 \mathrm{mM}$ dan pada perlakuan 2 (pakan yang ditambahkan molases) yaitu 58,33 Mm yang hasilnya lebih rendah jika dibandingkan dengan penelitian yang dilakukan $\mathrm{Mc}$
Donald et al. (1995) yang menyatakan bahwa produksi VFA (Volatile fatty acid) yang baik untuk memenuhi sintesis mikrobia rumen yaitu sekitar $70-150 \mathrm{mM}$.

Kondisi $\mathrm{pH}$ dalam rumen pada penelitian ini berkisar antara 6,55 - 6,63 yang menunjukan bahwa baik dan ideal untuk pertumbuhan mikroorganisme, karena nilai $\mathrm{pH}$ dalam rumen akan berpengaruh terhadap proses fermentasi dalam rumen. Apabila $\mathrm{pH}$ baik maka proses fermentasi dalam rumen akan baik, dan sebaliknya apabila nilai $\mathrm{pH}$ dalam rumen kurang ideal maka akan menghambat proses fermentasi sehingga akan berpengaruh terhadap aktivitas mikrobia dalam rumen. Puastuti et al. (2010) menyatakan bahwa $\mathrm{pH}$ normal dalam rumen merupakan kondisi yang diperlukan agar proses fermentasi dapat berjalan dengan baik. Apabila nilai $\mathrm{pH}$ dalam rumen kurang dari 6 maka aktivitas mikrobia rumen akan terganggu dan proses fermentasipun akan terganggu pula, karena akan menurunkan populasi mikrobia dalam rumen, sehingga akan mempengaruhi aktivitas mikrobia selulolitik dalam mencerna dinding sel tanaman.

\section{Produksi Protein Mikrobia Rumen}

Hasil produksi protein mikrobia pada T1 dan T2 berturut-turut adalah 413,89 mg/g dan $432,77 \mathrm{mg} / \mathrm{g}$. Hasil yang diperoleh lebih tinggi jika dibandingkan dengan hasil penelitian Widiastuti dan Susanti (2008) yang menyatakan bahwa sintesis protein mikrobia pada pakan komplit dengan menggunakan bahan dasar limbah pertanian berupa jerami padi dengan komposisi TDN $70,02 \%$ dan PK 16,53\% yaitu sebesar 124,12 $\mathrm{mg} / \mathrm{ml}-188,24 \mathrm{mg} / \mathrm{ml}$. Waldi et al. (2017) menyatakan bahwa sintesis protein mikrobia rumen pada pakan dengan menggunakan komposisi TDN 59,99 - 61,75\% dan PK 11,91 - 12,87\% yaitu sebesar 123,79 $\mathrm{mg} / 20 \mathrm{ml}-227,56 \mathrm{mg} / 20 \mathrm{ml}$. Perbedaan hasil produksi protein mikrobia yang diperoleh bisa disebabkan karena komposisi pakan dan bahan pakan yang digunakan juga berbeda. Hal ini sesuai dengan pendapat Wati et al. 
(2012) yang menyatakan bahwa setiap bahan pakan memiliki kemampuan degradasi yang berbeda, sehingga tingkat sintesis juga berbeda.

Semakin tinggi nilai produksi protein mikrobia yang diperoleh maka akan semakin baik, karena tingginya produksi protein mikrobia akan berpengaruh terhadap proses degradasi pakan dalam rumen. Suryani et al. (2014) menyatakan bahwa jumlah produksi protein mikrobia akan berpengaruh terhadap laju degradasi pakan dalam rumen. Tingginya protein pakan juga harus diimbangi dengan energi, agar energi-protein pakan dapat seimbang. Ginting (2005) menyatakan bahwa ketersediaan energiprotein dalam pakan yang disusun harus seimbang. Apabila jumlah energi yang tersedia melampui ketersediaan $\mathrm{N}$, maka pertumbuhan mikrobia dan efisiensi fermentasi dalam rumen akan menurun. Widiyastuti dan Susanti (2008) menyatakan bahwa kandungan protein yang tinggi harus diimbangi dengan kandungan energi bahan pakan yang tinggi dengan tujuan agar hasil degradasi protein dalam rumen yaitu $\mathrm{NH}_{3}$ dapat dimanfaatkan oleh mikrobia rumen untuk sintesis protein mikrobia. Widyobroto et al. (2007) menyatakan bahwa produksi protein mikrobia dapat ditingkatkan dengan adanya keseimbangan antara energi dan $\mathrm{N}$ yang tersedia dalam pakan, perbaikan sinkronisasi energi dan protein yang dibebaskan dalam rumen dapat meningkatkan sintesis protein mikrobia.

Hasil diatas menunjukan bahwa produksi protein mikrobia yang tedapat dalam tepung bonggol pisang dan molases tidak berbeda nyata $(p>0,05)$ yang berarti kedua perlakuan memiliki kesamaan. Hal tersebut disebabkan karena ransum yang diformulasikan dengan persentase PK dan TDN yang sama yaitu $\pm 12 \%$, dan $\pm 60 \%$ sehingga produksi protein mikrobia yang dihasilkan sama karena protein mikrobia dalam rumen dibentuk karena adanya protein pakan sebagai penyuplai sumber $\mathrm{N}$ yang akan dirombak melalui tahap-tahap tertentu. Hal ini sesuai dengan pendapat Mahesti (2009) yang menyatakan bahwa proses degradasi protein yaitu proses perubahan protein pakan menjadi peptida dan asamasam amino oleh mikroba rumen, selanjutnya asam-asam amino tersebut mengalami deaminasi sehingga menghasilkan asam $\alpha$ keto dan amonia. Asam $\alpha$ keto dan amonia kemudian dimanfaatkan untuk sintesis protein mikroba. Suryani et al. (2014) menyatakan bahwa tingginya komposisi protein mikrobia dalam rumen berbanding lurus dengan komposisi protein dalam pakan, karena protein kasar merupakan komponen yang sangat menentukan untuk sintesis protein mikroba dan protein kasar mengindikasikan ketersediaan unsur $\mathrm{N}$ bagi mikroba rumen. Ginting (2005) menyatakan bahwa dalam berbagai situasi pakan, asam amino yang tersedia bagi produksi ternak sebagian besar berasal dari protein mikrobia rumen. Kontribusi protein mikrobia diperkirakan mencapai 60 - 70\% dari total asam amino atau protein yang diserap oleh ternak.

Kesamaan nilai produksi protein disebabkan karena komposisi TDN yang disusun dalam pakan juga sama yaitu $\pm 60 \%$, sehingga nilai produksi protein yang dihasilkan dari kedua perlakuan hampir sama. Produksi protein mikrobia juga dapat dipengaruhi oleh ketersedian N, VFA dan kerangka karbon dalam pakan, karena ketersediaan N, VFA dan kerangka karbon dapat meningkatkan produksi protein mikrobia sehingga akan berpengaruh pula terhadap degradasi bahan kering dan bahan organik pakan. Hal ini sesuai dengan pendapat Putra (2006) dan Widyobroto et al. (2007) yang menyatakan bahwa produksi protein mikrobia sangat dipengaruhi oleh ketersediaan $\mathrm{N}$ dan ketersediaan energi (VFA). Ketersediaan VFA dan $\mathrm{NH}_{3}$ yang cukup dapat meningkatkan sintesis protein mikrobia, sehingga pada akhirnya dapat meningkatkan degradasi bahan kering dan bahan organik pakan. Bata (2008) menyatakan bahwa VFA pakan dapat dimanfaatkan langsung oleh mikrobia rumen sebagai sumber energi untuk memanfaatkan protein sebagai sumber $\mathrm{N}$ untuk sintesis protein mikrobia. Semakin rendah nilai VFA 
maka semakin banyak pula VFA yang digunakan sebagai sumber energi oleh mikrobia rumen untuk sintesis protein mikrobia.

\section{Degradasi Bahan Kering}

Persentase degradasi bahan kering dari T1 dan T2 pada pakan komplit adalah $68,99 \%$ dan $67,01 \%$. Hasil yang diperoleh lebih tinggi dari hasil degradasi bahan kering yang dilaporkan oleh Firsoni dan Yunita (2014) yang menyatakan bahwa hasil pengukuran degradasi bahan kering pada pakan komplit setelah 48 jam inkubasi yang dilakukan secara in vitro dengan kandungan PK $10,15 \%-15,07 \%$ pada berbagai perlakuan yaitu $61,38 \%-64,13 \%$. Tingginya hasil persentase degradasi bahan kering pakan yang diperoleh, menunjukan bahwa semakin tinggi pula kualitas pakan tersebut. Hal ini sesuai dengan pendapat Riswandi et al. (2015) yang menyatakan bahwa persentase degradasi pakan berbanding lurus dengan kualitas pakan, dimana semakin tinggi nilai degradasi pakan maka semakin tinggi pula kualitas pakan tersebut. Nilai degradasi yang tinggi mencerminkan besarnya sumbangan nutrien tertentu pada ternak, sedangkan pakan yang mempunyai nilai degradasi yang rendah menunjukkan bahwa pakan tersebut kurang mampu menyuplai nutrien.

Hasil diatas menunjukan bahwa pakan komplit dengan penambahan tepung bonggol pisang tidak berbeda nyata $(p>0,05)$ terhadap persentase degradasi bahan kering, hal ini disebabkan karena kandungan serat kasar dalam pakan perlakuan 1 dan perlakuan 2 rendah atau tidak terlalu tinggi. Kandungan serat kasar dalam pakan sangat berpengaruh terhadap laju degradasi bahan kering dalam rumen. Tepung bonggol pisang dan molases memiliki nilai NFC yang hampir sama yaitu $18,07 \%$ dan $18,27 \%$ (Tabel 1. dan 2.) sehingga hasil degradasi pakan yang dihasilkan juga hampir sama.

Kesamaan nilai NFC pada kedua perlakuan menunjukan bahwa tidak ada pengaruh apabila molases di substitusi dengan tepung bonggol pisang sebagai sumber karbohidrat dalam penyusunan pakan komplit. Tepung bonggol pisang juga memiliki keistimewaan yang sama yaitu memiliki daya cerna yang tinggi, karena tepung bonggol pisang merupakan sumber karbohidrat yang memiliki serat kasar yang rendah atau non fiber carbohydrate. Hal ini sesuai dengan pendapat Tillman et al. (1998) yang menyatakan bahwa bahan pakan yang memiliki serat kasar yang rendah pada umumnya akan lebih mudah dicerna, karena dinding sel dari bahan tersebut tipis sehingga mudah di tembus. Riswandi et al. (2015) menyatakan bahwa tinggi rendahnya degradasi nutrien dipengaruhi oleh kandungan serat kasar dan aktivitas mikroorganisme rumen terutama bakteri selulolitiknya. Hal ini sesuai dengan pendapat Nurjanah et al. (2016) yang menyatakan bahwa faktor yang dapat mempengaruhi degradasi bahan kering yaitu kandungan serat kasar yang terdapat dalam pakan. Kandungan serat kasar yang rendah akan meningkatkan nilai degradasi pakan karena mikrobia rumen lebih mudah dalam mendegradasi pakan.

\section{Degradasi Bahan Organik}

Nilai degradasi bahan organik pakan komplit pada perlakuan 1 dan perlakuan 2 adalah $69,69 \%$ dan $65,74 \%$. Nilai tersebut lebih tinggi jika dibandingkan dengan hasil penelitian yang dilakukan oleh Firsoni dan Yunita (2014) yang menyatakan bahwa hasil pengukuran degradasi bahan organik pada pakan komplit yang diuji secara in vitro dengan kandungan PK 10,15\% - 15,07\% pada berbagai perlakuan yaitu sebesar $61,64 \%$ - 64,34\%. Nilai degradasi bahan organik lebih tinggi jika dibandingkan dengan nilai degradasi bahan kering, itu disebabkan karena dalam proses degradasi bahan kering pakan masih mengandung abu, sedangkan dalam proses degradasi bahan organik sudah tidak mengandung abu, sehingga pakan akan lebih mudah dicerna. Hal ini sesuai dengan pendapat Fathul dan Wajizah (2010) yang menyatakan bahwa nilai degradasi bahan organik lebih tinggi dibanding dengan nilai bahan kering, 
disebabkan karena pada bahan kering masih terdapat kandungan abu, sedangkan pada bahan organik tidak mengandung abu, sehingga bahan tanpa kandungan abu relatif lebih mudah dicerna. Kandungan abu memperlambat atau menghambat tercernanya bahan kering dalam pakan.

Hasil diatas menunjukan bahwa pakan komplit dengan tambahan tepung bonggol pisang dan pakan komplit dengan tambahan molases tidak berpengaruh nyata ( $p>0,05)$ terhadap nilai degradasi bahan organik pakan yang berarti perlakuan 1 dan perlakuan 2 memiliki kesamaan. Hasil degradasi yang diperoleh termasuk baik, yang berarti kemampuan mikrobia rumen dalam mendegradasi pakan juga baik. Degradasi bahan organik pakan dipengaruhi oleh kandungan serat kasar dalam pakan, apabila kandungan serat kasar tinggi maka kemampuan mikrobia dalam rumen akan rendah karena pakan akan sulit didegradasi, dan sebaliknya apabila serat kasar rendah maka pakan akan lebih mudah didegradasi sehingga persentase degradasi pakan akan tinggi. Hal ini sesuai dengan pendapat Suprapto et al. (2013) yang menyatakan bahwa serat kasar memiliki hubungan yang relatif dengan kemampuan degradasi, semakin rendah serat kasar maka semakin tinggi degradasi pakan. Kuryaningtyas et al. (2012) menyatakan bahwa degradasi bahan organik pakan merupakan bagian dari bahan kering pakan, sehingga apabila degradasi bahan kering tinggi makan degradasi bahan organik juga akan lebih tinggi dan sebgaian besar bahan organik merupakan komponen bahan kering.

\section{KESIMPULAN}

Hasil penelitian menyimpulkan bahwa bahwa tepung bonggol pisang dapat menggantikan molases sebagai sumber karbohidrat pada pakan komplit.

\section{DAFTAR PUSTAKA}

Amri, U dan Yurleni. 2014. Efektivitas pemberian pakan yang mengandung minyak ikan dan olahannya terhadap fermentasi rumen secara in vitro. Jurnal Ilmiah Ilmu-Ilmu Peternakan. 17 (1): 22-30.

Assakur, M.S. 2013. Degradasi Bahan Kering, Nilai $\mathrm{pH}$ dan Produksi Gas Sistem Rumen In Vitro terhadap Kulit Buah Kakao (Theobroma cacao) yang Diberi Perlakuan Berbeda. Fakultas Peternakan Universitas Hasanuddin, Makassar. (Skripsi).

Bata, M. 2008. Pengaruh molases pada amoniasi jerami padi menggunakan urea terhadap kecernaan bahan kering dan bahan organik in vitro. Agripet. 8 (2): 15-20.

Firsoni dan R. Yunita. 2014. Uji degradabilitas pakan komplit yang mengandung daun Chromolaena odorata secara in vitro. Jurnal Peternakan Indonesia. 16 (2): 89-95.

Ginting, S.P. 2015. Sinkronisasi degradasi protein dan energi dalam rumen untuk memaksimalkan produksi protein mikroba. Wartazoa. 15 (1) : 1-10.

Indah, A.S. 2016. Kandungan Protein Kasar dan Serat Kasar Silase Pakan Lengkap Berbahan Utama Batang Pisang (Musa paradisiaca) dengan Lama Inkubasi yang Berbeda. Fakultas Peternakan Universitas Hasanuddin, Makassar. (Skripsi).

Indayani, D. 2014. Pengaruh Pemberian Wafer Pakan Komplit yang Mengandung Berbagai Level Tongkol Jagung terhadap Konsumsi Bahan Kering, Bahan Organik, dan Protein Kasar pada Kambing Kacang Jantan. Fakultas Peternakan, Universitas Hasanuddin, Makassar. (Skripsi).

Komar, A. 1984. Teknologi Pengolahan Jerami sebagai Makanan Ternak. Yayasan Dian Grahita, Bandung.

Kuryaningtyas, I.B., P.R. Pandansari., I. Astuti., S.D. Widyawati dan W.P.S. 
Suprayogi. 2012. Pengaruh macam akselerator terhadap kualitas fisik, kimiawi dan biologis silase rumput kolonjono. Tropical Animal Husbandry. 1 (1): 7-14.

Mahesti, G. 2009. Pemanfaatan Protein pada Domba Lokal Jantan dengan Bobot Badan dan Aras Pemberian Pakan yang Berbeda. Fakultas Peternakan Universitas Diponegoro, Semarang. (Skripsi).

Mc. Donald, P., R.A. Edward and J.F.D. Grenhals. 1995. Animal Nutrition. Huntsman Offset Print Ltd. Singapore. pp $42-153$.

Nurjanah, I., Mashudi dan H. Sudarwati. 2016. Produksi gas, degradasi bahan kering dan bahan organik secara in vitro silase pakan lengkap berbasis pucuk tebu (Saccharum officinarum) dan jenis leguminosa berbeda. 1-14.

Puastuti, W., D. Yulistiani., I.W. Mathius., F. Giyai dan E. Dihansih. 2010. Ransum berbasis kulit buah kakao yang disuplementasi $\mathrm{Zn}$ organik: respon pertumbuhan pada domba. JITV. 15 (4): 269-277.

Plummer, D.T. 1971. An Introduction to Practical Biochemistry. McGraw-Hill Publ, London.

Putra, S. 2006. Pengaruh suplementasi agensia defaunasi waktu inkubasi terhadap bahan kering, bahan organik terdegradasi dan produk fermentasi secara in vitro. Animal Production. 8 (2): 121-130.

Riswandi., Muhakka dan M. Lehan. 2015. Evaluasi nilai kecernaan secara in vitro ransum ternak sapi bali yang di seplementasi dengan probiotik bioplus. Jurnal Peternakan Sriwijaya. 4 (1): 35 46.

Suhada, A.T., L. K. Nuswantara., E. Pangestu., F. Wahyono and J. Achmadi.
2016. Effect of synchronization of carbohydrate and protein supply in the sugarcane baggase based diet on microbial protein synthesis in sheep. J. Indonesian Trop. Anim. Agric. 41 (3): 135-144.

Suprapto, H., F.M. Suhartanti dan T. Widiyastuti. 2013. Kecernaan serat kasar dan lemak kasar complete feed limbah rami dengan sumber protein berbeda pada kambing etawa lepas sapih. Jurnal Ilmiah Peternakan. 1 (3): 938-946.

Suryani, N.N., I.K.M. Budiasa dan I.P.A. Astawa. 2014. Fermentasi rumen dan sintesis protein mikroba kambing peranakan ettawa yang diberi pakan dengan komposisi hijauan beragam dan level konsentrat berbeda. Jurnal Ilmiah Peternakan. 17 (2): 56-60.

Sutowo, I., T. Adelina dan D. Febrina. 2016. Kualitas nutrisi silase limbah pisang (batang dan bonggol) dan level molases yang berbeda sebagai pakan alternatif ternak ruminansia. Jurnal Peternakan. 13 (2): 41-47.

Tilley, J. M., dan R.A. Terry. 1969. A two stage technique for in- vitro digestion of forage crops.J. Br. Grassland Society 18 (2): $104-111$.

Tillman, D.A., H. Hartadi dan S. Reksohadiprodjo. 1996. Ilmu Makanan Dasar Ternak. Gadjah Mada University Press, Yogyakarta.

Usman, Y. 2013. Pemberian pakan serat sisa tanaman pertanian (jerami kacang tanah, jerami jagung, pucuk tebu) terhadap evolusi $\mathrm{pH}, \mathrm{N}-\mathrm{NH}_{3}$ dan VFA di dalam rumen sapi. Jurnal Agripet. 13 (2): 53-58.

Waldi, L., W. Suryaprtama dan F.M. Suhartati. 2017. Pengaruh penggunaan bungkil kedelai dan bungkil kelapa dalam ransum berbasis indeks sinkronisasi energi dan protein 
terhadap sintesis protein mikrobia rumen sapi perah. Journal of Livestock Science and Production. 1 (1): 1-12.

Wati, N.E., J. Achmadi dan E. Pangestu. 2012. Degradasi nutrien bahan pakan limbah pertanian dalam rumen kambing secara in sacco. Animal Agriculture Journal. 1 (1): 485-498.

Widyobroto, B.P., S.P.S. Budhi dan A. Agus. 2007. Pengaruh aras undegraded protein dan energi terhadap kinetik fermentasi rumen dan sintesis protein mikroba pada sapi. Jurnal Indonesian Tropical Animal and Agriculture. 32 (3): 194-200.
Widiastuti, T dan E. Susanti. 2008. Produk fermentasi rumen dan sintesis protein mikrobia dari complete feed block berbahan dasar limbah pertanian dengan proses amoniasi dan penggunaan berbagai binder. Seminar Nasional Teknologi Peternakan dan Veteriner. Fakultas Peternakan Universitas Jenderal Soedirman, Purwokerto. Hal. 836-842.

Yuliana, S. 2008. Uji Kualitas Fisik Ransum Komplit dalam Bentuk Wafer Berbahan Baku Jerami Padi Produk Fermentasi Trichoderma viride. Fakultas Peternakan, Institut Pertanian Bogor. Bogor. (Skripsi). 